\title{
Conditions of Diffusion of Competitiveness Clusters' Technologies: A Brief Theoretical Note
}

\author{
B. G. Jean Jacques Iritié ${ }^{1}$ \\ ${ }^{1}$ Département de Gestion, Commerce et Economie Appliquée (GCEA), Institut National Polytechnique Félix \\ Houphouet Boigny (INP-HB), Yamoussoukro, Côte d'Ivoire \\ Correspondence: B. G. Jean Jacques Iritié, Département GCEA/INP-HB, B.P. 1874 Yamoussoukro, Côte \\ d'Ivoire. Tel: 225-5967-2812. E-mail: jeanjacques.iritie@gmail.com
}

Received: July 22, 2015

doi:10.5539/ijef.v7n10p66
Accepted: August 25, 2015

Online Published: September 25, 2015

URL: http://dx.doi.org/10.5539/ijef.v7n10p66

\begin{abstract}
Competitiveness clusters (or innovation clusters) are the focal point of French new industrial policy. They are based on classical cluster model and its well-known agglomeration positive externalities and on benefits of cooperation. After a brief literature review of cluster theory, we focus on the theoretical conditions under which French innovation clusters can foster production and diffusion of technological innovations. Our short critical analysis points out three non-exhaustive conditions: (i) the capacity to coordinate and to incitate cooperation in R\&D; (ii) the capacity to favor production and technological knowledge transfer; (iii) the capacity to promote and to keep R\&D appropriation by cooperating innovators.
\end{abstract}

Keywords: innovation cluster, coordination, R\&D cooperation, knowledge spillovers, network externalities, installed base, absorptive capacity, collective appropriation

\section{Introduction}

Since the advent of what is now called the economics of knowledge after the seminal book of Fritz Machlup entitled "The Production and distribution of knowledge in the United States" published in 1962, research and innovation activities have become over the years the main factors of growth and competitiveness of firms in industrialized countries. This is how to face strong international competition and relocation of its firms in the early 2000s, France has undertaken in 2004 a new industrial policy based on the model of clusters and using scientific, technological and organizational innovation. This is the innovation clusters-based industrial policy called "competitiveness clusters". The basic idea of competitiveness clusters is to promote cooperation between business networks, territories skills and innovation in order to create an innovative environment to strengthen firms competitiveness, employment and growth. Formally, a competitiveness cluster has been defined as "the combination, on a given territory, of companies, training centers and public and private research units engaged in a partnership in order to create synergies around common innovative projects"(Marcon, 2008).

The collaborative R\&D projects figure prominently in the new industrial policy and their funding comes from public funds (Unique Interministerial Fund or FUI), state agencies (ANR, OSEO) and local authorities. The $R \& D$ projects are seen as a way of structuring cooperation relationship (Dessertine, 2014). Today, there are 71 active competitiveness clusters in various sectors and especially in high-tech sectors such as nanotechnology and embedded software, renewable energy, biotechnology. However since its implementation, the competitiveness cluster raises many questions in scientific communities. One of the first concerns is the issue of its governance and coordination of different actors (Tixier \& Castro-Gonçalves, 2008; Défélix et al., 2009; Gomez, 2009; Retour, 2009). Indeed, each competitiveness cluster has its own mode of governance, in most cases, an association composed of industrial actors, academic and local authorities. This governance involves a positive sum game, a mix of cooperation and competition, between the actors. Thus, how the internal organization of clusters is managed to converge towards common projects of actors who are subject to different legal rules and taxes and whose interests are diverse natures and time horizons. In other words, this goes back to the question of the ability of competitiveness clusters to generate cooperation between actors. Another issue closely related to the first is the role of competitiveness clusters in encouraging production and diffusion of technology innovations. Finally and more generally, in terms of public policy, the new policy raises the question of its role in the articulation of the public/private research policy and industrial policy. It is thus clear that the adequate 
theory of competitiveness clusters is necessary in the sense that the governance of clusters depends on both the degree of convergence of actors towards joint $R \& D$ projects and the development of an innovative environment capable of incitating, produce and favor sharing and dissemination of new knowledge.

This short paper is a reflection on the question of the diffusion of clusters' technology innovations. Thus, through a theoretical approach based on a critical view of the economic literature of clusters, we try to analyze and understand the conditions in which competitiveness clusters can participate in the creation, development of innovative products and processes and their dissemination. For us, three non-exhaustive conditions are necessary: the ability of comptitiveness clusters to coordinate and foster cooperation between actors, their ability to promote production and technology transfer and their ability to promote and secure the appropriation of R\&D outputs.

The rest of the paper is organized as follow. In the section 2, we highlight the theoretical framework of the competitiveness clusters policy. Section 3 is dedicated to the critical reflection on the conditions in which competitiveness clusters can serve as a support for the production and diffusion of technological innovations. Section 4 concludes the paper.

\section{Cluster-Based Industrial Policy: An Overview}

It is now well-accepted in the economic literature that innovation is the main driver of economic growth (Solow, 1956). At firm level, innovation is seen as the price to stay on the market. However, innovation activity is inherently uncertain, disorderly and built from complex systems that often require adequate coordination of technical knowledge (Kline \& Rosenberg, 1986). According to neoclassical theory only the market (through prices mechanism and competition) has the ability to coordinate economic actors for optimal allocation of resources. In the field of technology, market relationship should therefore encourage involved actors in the creation and use of new knowledge but also regulate and compensate fluctuations in supply and demand (Maskell \& Lorenzen, 2004). The market coordination may be sub-optimal in the presence of significant transaction costs related to price mechanisms. Moreover according to Arrow (1962) the market mechanism results in sub-optimal allocation of resources of knowledge in the production of innovation. This is explained by the fact that innovation has a public good feature and its appropriation by innovators remains imperfect. The difficulty of appropriation of the results of $R \& D$ reduces incentives to innovate. Therefore, firms under-invest in research and development even if there is a strong system of intellectual property.

To encourage R\&D activities and boost firms competitiveness and growth, public policy-makers invest more public funds in supporting privates R\&D activities and promote collaborative research policy through localized and specialized structures such as clusters. Note that the concept of "cluster" was made famous by Michael Porter in the 1990s. According to Porter (2000), clusters are "geographic concentrations of interconnected companies, specialized suppliers, services providers, firms in related industries, and associated institutions (e.g. universities, standard agencies, trade associations) in a particular field that compete but also cooperate". Today, clusters have become the main strategy of industrial policies in Europe and elsewhere (Ketels, 2004). They are associated with firms progress and success in innovation, especially in the field of high technologies (Baptista, 1996). Even OECD uses clusters as the keys of development and growth (Martin \& Sunley, 2003). The EU's research and innovation policy gives priority to clusters as strategic policy tools for promoting innovation, increasing competitiveness and creating employment.

The implementation of competitiveness clusters is based on a dual logic: agglomeration and geographic proximity. In economic literature, we find the origin of competitiveness clusters in the Marshall's concept of industrial districts (Marshall, 1920). Indeed Marshall's observations on the concept of external economies in localized industries have generated several studies about the benefits of agglomeration and geographic proximity. We learned about that agglomeration is favored by increasing returns to scale and that it increases the intensity of interactions between actors co-located (Arthur, 1989; Ketels, 2004), promotes the availability of low-costs intermediate inputs and expertises, sharing of common and specialized infrastructures (Krugman, 1991). The agglomeration and proximity also facilitate the transfer and acquisition of tacit and complex knowledge between firms and increase their absorption capacity (Jaffe et al., 1993; Cohen \& Levinthal, 1990; Audretsch and Feldman, 1996). In this sense, a cluster provides a local competitive advantage. Clusters promote the strengthening of the network dynamics of companies and therefore enable risk sharing and reduction of static and dynamics uncertainty related to innovation.

In addition to the specificity of competitiveness clusters, note that the definition of competitiveness clusters policy explicitly consider the influence of historical trajectories and organizational contexts of local territories on the dynamics of innovation. In other words, the configuration of the French innovation clusters is characterized by the path dependency (Note 1) of the host localities. It therefore takes into account their values, R\&D capacity, 
industry specialization, historical events, institutional arrangements and means. Thus, because the sectorial specialization in repeated interactions between actors necessarily involves specific assets, a cluster theoretically acquires a competitive advantage but is exposed to the phenomenon of "cluster lock-in", i.e enclosing on itself and so its inability to exchange and interact with the outside.

Furthermore, several studies covered the shortcomings of clusters. According to Martin and Sunley (2003) the concept is fuzzy and is simply a political tool rather than operational. Baptista (1996) shows that the dynamics of clusters can be a victim of congestion effects such as urban congestion, pollution and the difficulty of coordination between actors. This raises the question of the optimal size or critical mass of competitiveness clusters. In addition, accroding to Giuliani (2007) and Maskell and Lorenzen (2004), there is a structural difference between clusters and business networks. According to the authors, business networks are characterized by dense dynamic relationships based on mutual trust, so that clusters are simple knowledge-sharing networks; Giuliani (2007) empirically shows that knowledge spillovers only benefit a small number of firms in clusters. So there is not necessarily conceptual relationship between cluster and potential innovation. Another limitation of agglomeration is the effect of competition that could engage co-located firms to capture the rent and the risk of homogenisation of activities.

\section{Diffusion of Clusters' Technologies: Conditions}

The research on the diffusion of innovations is abundant in IO's literature. The diffusion of an innovation is defined as the process by which innovation is transmitted and/or adopted in time by consumers (Rogers, 2003). Several factors may explain the diffusion: supply and demand (Griliches, 1957), trade-off between benefits and costs of adoption, information and uncertainty on innovation, social and industrial environment (Geroski, 2000; Hall, 2003) and communication (Rogers, 2003). The factors that explain diffusion rate may be endogenous or exogenous. The endogenous factors are the intrinsic characteristics of products and innovative processes while exogenous factors are those related to the socio-cultural environment and industrial organization. In this study, we consider a competitiveness cluster as an external factor and we are interested in its role as an industrial organization or a support enabling co-production and diffusion of technological innovations. For us, the ability of the French innovation clusters to facilitate the production and diffusion of technological innovations must obey three non-exhaustive conditions: (i) its ability to coordinate the actors and stimulate R\&D cooperation, (ii) its ability as industrial organization to produce knowledge and to facilitate its transfer, (iii) its ability to promote and secure appropriation of $R \& D$ outputs by innovative firms in cooperation.

\subsection{Coordination and $R \& D$ Cooperation}

The competitiveness clusters will promote co-production and diffusion of new knowledge if they really generate good strategic interactions and cooperation between actors around common projects. However, geographical proximity aroused by competitiveness clusters does not guarantee the existence of dense relationships. It does not constitute a necessary coordination support to cooperation between economic agents (Mendez, 2008); it seems rather that geographical proximity is decisive for the most upstream phases of the production of innovations (Carré et al., 2008). Moreover, unlike most clusters and industrial districts, the designing and structuring of competitiveness clusters have not made spontaneously. The policy of competitiveness clusters was driven by the French State as a new industrial policy; then we can assume that some competitiveness clusters were created for the unique purpose of responding to the opportunity offered by the State for the territories. In this case, it would be called occasional cooperation for the capture of public funds. But even assuming that the policy is set up according to the real potential of stakeholders and territories, the network of actors that started moving inside each competitiveness cluster does not guarantee the quality of relations between them. So, the role of the cluster in the co-production of knowledge is either to activate or to strengthen links between actors who ignore each other.

The co-production of technological knowledge requires a common or convergent vision; hence the importance of the central role of the governance structure as a coordination and emergence structure of cooperation between actors. According to Calamel et al. (2012), coordination refers to deliberate and intentional actions to structure the partnership activities inside the cluster. It therefore requires a mandatory hierarchic process based on procedures while cooperation rather requires voluntary mutual adjustment. It is therefore for the cluster governance structure firstly to define common strategies for alignment or convergence of cognitive and technological capabilities and expectations of stakeholders, and also to bring out collaboratives projects. The issue of governance leads up to the question of effective integration of small and medium enterprises and their role in the choice of collaborative $R \& D$ projects. We note that to promote the dynamic of business network and the emergence of collaborative R\&D projects, clusters often proceed by fairs of projects (e. g. competitiveness 
cluster Minalogic), innovation workshops (e. g. competitiveness cluster Techtera), calls for internal projects (e. g. competitiveness cluster Axelera) or collaborative days. But all these strategies do not remove the risk of seeing the establishment of a governance around large dominant firms which impose their rules to small firms. For instance, Bossard-Prechoux and Brechet (2009) showed that the process of emergence of collaborative projects is done in several steps and it starts around a core group of large companies to the peripheries composed mainly of small businesses. In fact a theoretical analysis of the structure of governance as a coordination support of cooperation between actors would be necessary to understand the logic of coordination within the competitiveness clusters. For this analysis, one could for example build on the work of Olson "The Logic of Collective Action: Public Goods and the Theory of Groups" published in 1971; the analysis should be complemented by empirical research on clusters.

In addition to the coordination issue, there is also the issue of cooperation around common projects. The governance structure should encourage cooperation relationship between clusters' members because the actors' motivation to cooperate is not "natural" but is acquired over time (Calamel et al., 2012). The inter-firms cooperation not only fits in a logical organization of transactions between contracting but also in a strategic sense, complementarity of firms for innovation (Abdessemed, 2001) (Note 2). Competitiveness clusters should be the privileged framework of inter-firms cooperation (Note 3) within the cluster and inter-clusters cooperation. Firms can not continue to manage knowledge in isolation; they do not always have all necessary information for implementation of their competitive strategy and more specifically their technological innovation strategy. So, this implies looking for additional information with other firms and research centers. To do this, cooperation relationship must be increasingly strengthened and contractualized. These relationships should involve both large companies and small ones. Small businesses should be helped and encouraged to be heavily involved to cooperate and interact. Within clusters, they will enjoy the benefits of cooperation that can be estimated in informational terms (i.e. network effects and spillovers) and non-informational terms (i.e. share of research costs and risk, high probability of successful innovation, etc.) (Note 4).

\subsection{Knowledge Production and Spillovers}

Whatever the model type, the diffusion of an innovation is based on the transfer of information (or new knowledge) from a transmitting source to a receiving entity. Production and transfer of knowledge are central in the competitiveness clusters policy. The clusters will get local competitive advantage in the ease with which they allow the transfer and acquisition of knowledge especially tacit knowledge between co-located firms. Indeed, this form of knowledge is supposed spatially less mobile and the dissemination of related technology is possible through personal contacts and by word-of-mouth (Maskell \& Malmerg, 1999). This was showed by Geroski (2000) et Rogers (2003) (Note 5). The learning of such technology is through a regular practice. Therefore, localized activities facilitate the development of collective learning process and increase innovations diffusion rate. But for that, a competitiveness cluster must: (i) create an enabling environment and be a kind of an installed base of innovations through the network of actors in motion, (ii) promote increase of its organizational absorptive capacity and also boost individual firms absorptive capacity.

\subsubsection{Cluster as an Installed Base of Innovations}

The diffusion process is often facilitated by the positive network externalities. We note that there are positive network externalities (Note 6) when an innovative product becomes more valuable for a user with increased number of adopters users for the same product or compatible products (Tirole, 1988). This effect can be direct or indirect when there is an increase in the value of innovation following a large number of complementary products on the market. A competitiveness clusters, being composed of networks, can be seen as an "installed base" or a support of innovations especially when there is a dense network. An installed base measures the number of sold units and currently in use; it is not to be confused with the market share that reflects only the sales in a given period. The positive effect of network is operated within the competitiveness clusters through the sharing of knowledge and information. Thus, the clusters can facilitate the coordination of expectations on the choice of technologies to adopt. Indeed, more a cluster promotes exchanges, communications and R\&D cooperation agreements between actors, more classical inefficiencies are generated in networks, i.e excess inertia and excess precipitation (Note 7), will be avoided. The competitiveness clusters as installed bases of innovations through dense networks can act for the establishment of norms and technology standards and encourage firms to make compatible their innovations in order to promote diffusion and adoption.

\subsubsection{Cluster as a "Booster" of Firms Absorptive Capacity}

The absorptive capacity of a competitiveness cluster as industrial organization can play an important role in the production and transfer of innovations. The concept of absorptive capacity was introduced by Cohen and 
Levinthal (1989). According to the authors, R\&D investments not only serve to generate innovation but also to develop and maintain the absorptive capacity. The absorptive capacity of an organization is its ability to recognize, understand, and exploit the flow of new information (or spillovers) from other organizations. As defined, the absorptive capacity defines some "productivity" of spillovers: the bigger it is, the higher the spillovers have effect on the organization's productivity. The development of the absorptive capacity is by learning. In the case of clusters, it depends on previous accumulated stock of knowledge, type of technological knowledge and structure of coordination and internal communication. However, the factors that encourage organizations to learning are the amount of knowledge to assimilate and exploit and the difficulty of learning (Cohen \& Levinthal, 1990). Learning is difficult in an environment that has not accumulated prior knowledge and then becomes very expensive. However, we can safely state that two specificities of competitiveness clusters promote the strengthening of their absorptive capacity and so boost individual firms absorptive capacity. First, the dependency of technological trajectories (or path dependency) that allows learning at low cost and second, the large number of actors in interaction. Competitiveness clusters are therefore a "natural" environment conducive to learning, so the diffusion and adoption of innovations. They therefore need to densify the network and the interactions between firms.

Finally, competitiveness clusters need to diversify their knowledge base to increase the absorption capacity of individual firms and so limit the effect of uncertainty. Indeed, the ease of learning is also affected by the degree with which an innovation is related to existing knowledge base. To do this, the structure of coordination and communication should promote cooperation agreements with other clusters, other external actors and firms and allow opening outwards.

\subsection{Collective Appropriation of Innovations}

The problem of appropriation of research outputs remains a critical issue in innovation diffusion process. Indeed, the "public good" feature of the information produced generates opportunistic behavior and low appropriation of innovation. So to encourage private innovation, instruments of appropriation and privatization of gains were designed (i.e. patents and licenses). In addition to these instruments there are also other public mechanisms, so-called socialization of costs mechanisms, such as research laboratories and public funds. The new clusters-based industrial policy can be located halfway of the two previous mechanisms (Crampes \& Encaoua, 2005). However the collective appropriation of innovation in the framework defined by this cluster policy could pose many problems of governance and regulation. Indeed firms engage in R\&D cooperation agreements because they expect to benefit from the results of research. The diffusion of innovation conditioned by R\&D activities also depends on the degree of appropriation of innovation. If the actors are uncertain about the outcome of $R \& D$ cooperation agreements, they will be reluctant to cooperate. The structure of coordination and communication of competitiveness clusters will therefore facilitate and secure business profits especially for small and medium enterprises. To do this, competitiveness clusters can integrate outside expertises for training, supports for actors in negotiations and pre-contract, post-contract procedures, confidentiality of information, sharing of results procedures, etc.

\section{Conclusion}

In this short paper, we tried to analyze conditions under which the French cluster policy can actively participate in the diffusion of technological innovations. The critical analysis based on literature review showed that clusters must be able to coordinate stakeholders in order to encourage inter-firm cooperation, promote the production and transfer of knowledge and finally to promote and secure the collective appropriation of the result of collaborative R\&D projects through training and supporting firm, especially SMEs, in intellectual property.

Note that, contrary to what was envisaged by policymakers, some characteristics of the competitiveness cluster policy are not necessarily in favor of behavior of effective and spontaneous cooperation between firms; these include for example the "top-down" approach used for the implementation of the policy, the technological specialization and geographical proximity whose positive impacts on cooperation are not clearly established. So, it will be up to the structure of governance of clusters to act for the alignment of cognitive and technological capabilities of firms in order to encourage cooperation in $R \& D$, actively involving SMEs. That is when the networks of actors in clusters could act as installed bases of innovation thus promoting standardization, complementarity, adoption and technology diffusion. Moreover, because of their technological path dependency, clusters act as natural environment for learning and for building both organizational and firms absorptive capacity. However, the time issue of organizational learning and adaptation of new external knowledge within clusters is essential to the success of this new policy. 


\section{References}

Abdessemed, T. (2001). Coopération inter-firmes: Mode de coordinantion hybride ou générique. In Xième Conférence de l'Association Internationale de management Stratégique du 13 au 15 juin 2001, Laval Canada.

Arrow, K. (1962). Economic welfare and the allocation of resources for invention. In The Rate and Direction of Inventive Activity: Economic and Social Factors (pp. 609-626). NBER Chapters, National Bureau of Economic Research, Inc.

Arthur, W. B. (1989). Competing technologies, increasing returns, and lock-in by historical events. Economic Journal, 99(394), 116-131. http://dx.doi.org/10.2307/2234208.

Audretsch, D. B., \& Feldman, M. P. (1996). Innovative clusters and the industry life cycle. Review of Industrial Organization, 11, 253-273. http://dx.doi.org/10.1007/BF00157670.

Baptista, R. (1996). Research round up: Industrial clusters and technological innovation. Business Strategy Review, 7(2), 59-64. http://dx.doi.org/10.1111/j.1467-8616.1996.tb00124.x.

Boivin, C., \& Vencatachellum, D. (1998). Externalités et coopération en recherche et développement: Une reconceptualisation. L'Actualité Economique, 74(4), 633-649. http://dx.doi.org/10.7202/602278ar.

Bossard-Prechoux, V., \& Brechet, J. P. (2009). Régulations et projets dans les pôles de compétitivité. Document de travail LEMNA No. 16.

Calamel, L., Defelix, C., Picq, T., \& Retour, D. (2012). Inter-organisational projects in french innovation clusters: The construction of collaboration. International Journal of Project Management, 30(1), 48-59. http://dx.doi.org/10.1016/j.ijproman.2011.03.001

Carré, D., Lefebvre, G., \& Madeuf, B. (2008). Les pôles de compétitivité, territoires d'innovation. Hermès, 50, 39-46.

Cohen, W. M., \& Levinthal, D. A. (1989). Innovation and learning: The two faces of R\&D. Economic Journal, 99, 569-596.

Cohen, W. M., \& Levinthal, D. A. (1990). Absorptive capacity: A new perspective on learning and innovation. Administrative Science Quarterly, 35(1), 128-152. http://dx.doi.org/10.2307/2393553.

Crampes, C., \& Encaoua, D. (2005). Microéconomie de l'innovation. In Encyclopedie de l'innovation (pp. 405-430).

D’Aspremont, C., \& Jacquemin, A. (1988). Cooperative and noncooperative R\&D in duopoly with spillovers. American Economic Review, 78(5), 1133-1137.

Défélix, C., Mazzilli, I., Retour, D., \& Picq, T. (2009). Piloter les projets d'innovation au sein des pôles de competitivité: Des leviers managériaux et humains. Finance Contrôle Stratégie, 12(4), 85-113.

Dessertine, M. (2014). Pôles de compétitivité et emploi: Une analyse micro-économique de l'effet des coopérations en $R \& D$. PhD thesis, University of Jean Monnet Saint-Etienne (France).

Geroski, P. A. (2000). Models of technology diffusion. Research Policy, 29, 603-625. http://dx.doi.org/10.1016/S0048-7333(99)00092-X.

Giuliani, E. (2007). Towards an understanding of knowledge spillovers in industrial clusters. Applied Economics Letters, 14(2), 87-90. http://dx.doi.org/10.1080/13504850500425907.

Gomez, P. Y. (2009). La gouvernance des pôles de compétitivité. Impasses théoriques et reformulation de la spécificité des pôles. Revue Française de Gestion, 10(190), 197-209.

Griliches, Z. (1957). Hybrid corn: an exploitation in the economics of technological change. Econometrics, 25, 501-522.

Hall, B. (2003). Innovation and Diffusion, chapter In J. Fagerberg, D. Mowery, \& R. R. Nelson (Eds.), Handbook of Innovation (pp. 459-484). Oxford University Press.

Jaffe, A. B., Trajtenberg, M., \& Henderson, R. (1993). Geographic localization of knowledge spillovers as evidenced by patent citations. The Quarterly Journal of Economics, 108(3), 577-598.

Ketels, C. H. (2004). Europeans clusters. Innovatives cities and business regions, 3. Bollschweil, Germany: Hagbarth Publications.

Kline, S. J., \& Rosenberg, N. (1986). An overview of innovation. In Landau, \& Rosenberg (Eds.), The positive 
Sum Strategy: Harnessing Technology for Economic Growth (pp. 275-305). National Academic Press.

Krugman, P. (1991). Increasing returns and economic geography. Journal of Political Economy, 99(3), 483-499.

Machlup, F. (1962). The Production and Distribution of Knowledge in the United States. Princeton, N.J., Princeton University Press.

Marcon, A. (2008). Les pôles de compétitivité: Faire converger performance et dynamique territoriale. Technical report, Avis du Conseil économique social.

Marshall, A. (1920). Principles of economics. MacMillan.

Martin, R., \& Sunley, P. (2003). Deconstructing clusters: Chaotic concept or policy panacea? Journal of Economic Geography, 3(1), 5-35. http://dx.doi.org/10.1093/jeg/3.1.5.

Maskell, P., \& Lorenzen, M. (2004). The cluster as market organization. Urban Studies, 41, 991-1009.

Maskell, P., \& Malmerg, A. (1999). Localised learning and industrial competitiveness. Cambridge Journal of Economics, 23(2), 167-185. http://dx.doi.org/10.1093/cje/23.2.167.

Mendez, A. (2008). Quelles articulations entre les pôles de compétitivité et les tissus productifs regionaux? Une mise en perspectives de quatre pôles en Provence-Alpes-Côte d'Azur. Technical report, LEST.

Miyagiwa, K., \& Ohno, Y. (2002). Uncertainty, spillovers, and cooperative R\&D. International Journal of Industrial Organization, 20(6), 855-876. http://dx.doi.org/10.1016/S0167-7187(01)00079-0

Penrose, E. T. (1959). The Theory of the Growth of the Firm. New York: Oxford University Press:

Porter, M. (2000). Location, competition, and economic development: Local clusters in global economy. Economic Development Quarterly, 14(1), 15-34. http://dx.doi.org/10.1177/089124240001400105.

Retour, D. (2009). Minalogic est un véritable écosystème d'innovation. Entretien avec nicolas leterrier. Revue Française de Gestion, 10(190), 169-177.

Rogers, E. M. (2003). Diffusion of innovations. New York: Free Press.

Solow, R. M. (1956). A contribution to the theory of economic growth. The Quarterly Journal of Economics, 70(1), 65-94. http://dx.doi.org/10.2307/1884513.

Tirole, J. (1988). The Theory of Industrial Organization. The MIT Press.

Tixier, J., \& Castro-Gonçalves, L. (2008). Les pôles de compétitivité à l'heure de l'évaluation: Quel modèle de "cluster à la française"? Réalités Industrielles, 103-110.

\section{Notes}

Note 1. The idea of "path dependency" resulted in a sentence taken from Penrose (1959): "the resources with which a particular firm is accustomed to working will shape the productive services its management is capable of rendering". This expresses the idea that the performance and firms or organizations trajectories are largely function of their particular history and routines they have accumulated.

Note 2. Abdessemed (2001) talks about "transactional approach" of cooperation based on the organization of transactions and related to asset specificity and "strategic approach" of cooperation resulting from the interdependence of firms and based on the joint production resources, innovation.

Note 3. For instance in the cluster Minalogic in Grenoble, one often distinguishes between two types of cooperation: outsourcing (asymmetric relationship) and cooperation properly spoken (symmetric relationship). But, the cooperation relationship is weakly contractualized and relatively informal.

Note 4. See for example the work of d'Aspremont and Jacquemin (1988), Boivin and Vencatachellum (1998) and Miyagiwa and Ohno (2002) and related works.

Note 5. According to Geroski (2000), the informational delay for the availability of a new technology may be the cause of differences in adoption time. However, it shows that the adoption of technology can be slower than the diffusion of related information. This is a typical example of "hardware" and "software" highlighted by Rogers (2003). Indeed, even if the source of knowledge exists and is common (e.g. impersonal manuals), diffusion of information (i.e. the software) is done through a experience of use. The knowledge transfer is done by word of mouth.

Note 6. Formally, there are positive network externalities when $\partial \mathrm{d}_{\mathrm{i}} / \partial \mathrm{D}_{-\mathrm{i}}(\mathrm{x})>0$ with $\mathrm{D}=\mathrm{D}_{-\mathrm{i}}+\mathrm{d}_{\mathrm{i}}$, which represents 
the total demand.

Note 7. These two inefficiencies often pose problems when the time information or reaction are long or when users have opposing preferences on norms and standards to choose.

\section{Copyrights}

Copyright for this article is retained by the author(s), with first publication rights granted to the journal.

This is an open-access article distributed under the terms and conditions of the Creative Commons Attribution license (http://creativecommons.org/licenses/by/3.0/). 